\title{
PETA SASTRA INDONESIA SASTRAWAN JAWA TIMUR
}

\author{
I. B. Putera Manuaba, Trisna Kumala SD, dan Adi Setijowati \\ FIB Universitas Airlangga Surabaya \\ e-mail: ibteram@yahoo.com
}

\begin{abstract}
Abstrak
Penelitian ini bertujuan mendeskripsikan peta sastra Indonesia sastrawan Jawa Timur. Pemetaan dimaksudkan mengungkapkan kekhasan sastra Indonesia yang diproduksi sastrawan daerah, khususnya sastrawan Jawa Timur. Metode yang digunakan adalah kualitatif-tekstual, dengan strategi pemerolehan data dokumentasi dengan teknik simakcatat. Hasil penelitian sebagai berikut. Pertama, sastra Indonesia sastrawan Jawa Timur lebih didominasi genre prosa (cerpen) dan puisi, serta memiliki kekhasan pengungkapan kearifan lokal Jawa Timur. Kedua, sastrawan Jawa Timur memiliki peta kekuatan memproduksi cerpen dan puisi dengan daerah basis Lamongan, Banyuwangi, Ngawi, Surabaya, Gresik, Sidoarjo, dan Sumenep.
\end{abstract}

Kata kunci: sastra Indonesia, sastrawan daerah, peta sastra, kearifan lokal

\section{THE INDONESIAN LITERATURE MAP BY EAST JAVA WRITERS}

\begin{abstract}
This study aims to describe the Indonesian literature map by East Java writers. The mapping is meant to reveal the uniqueness of the Indonesian literature created by local writers, especially East Java writers. The research method was qualitative and textual and the documentation data were collected through reading and note taking. The results of the study are as follows. First, the Indonesian literature by East Java writers is dominated by the prose genre (short stories) and poems and they have uniqueness to reveal local wisdom of East Java. Second, East Java writers have strengths to produce short stories and poems and their area bases are Lamongan, Banyuwangi, Ngawi, Surabaya, Gresik, Sidoarjo, and Sumenep.
\end{abstract}

Keywords: Indonesian literature, local writers, literature map, local wisdom

\section{PENDAHULUAN}

Karya-karya sastra Indonesia sastrawan daerah belum dikenal secara nasional ataupun internasional. Padahal karyakarya sastra sastrawan daerah cukup banyak jumlahnya di wilayah Indonesia. Jawa Timur, merupakan satu di antara daerah-daerah yang sastrawannya banyak memproduksi karya sastra Indonesia. Jawa Timur, sebagai daerah yang di masa lampau pernah menoreh sejarah kebesaran Kerajaan Majapahit dan juga sebagai tempat lahirnya karya-karya sastra besar seperti Negarakertagama dan Sutasoma, memiliki banyak sastrawan dengan karyakarya yang dihasilkannya. Banyaknya sastrawan yang tumbuh di Jawa Timur sangat berkait dengan latar belakang sejarahnya dan tidak dapat dilepaskan dengan "mata rantai" masa lampau.

Jawa Timur pada masa lampau menjadi daerah yang kaya dengan pengarang. Widarmanto (2013:93) mengatakan, mustahil sebuah tradisi sastra muncul begitu saja, pastilah sebuah tradisi terbentuk dari tradisi yang telah ada bertahun-tahun la- 
manya. Lebih jauh dikatakannya, di Jawa Timur tumbuhnya tradisi sastra berawal dari adanya pusat kerajaan, yang dimulai dari zaman Sri Kameswara, Airlangga, Jayabaya, hingga Hayam Wuruk, yang selanjutnya mengalami perubahan besar sejak kedatangan dan adanya pengaruh Islam.

Widarmanto (2013:95) menyebut ada juga teks-teks cerita Panji di masa Kerajaan Kediri. Pada zaman Majapahit ditulis kitab Pararaton (Katuturanira Ken Arok). Ada kitab Negarakertagama karya Mpu Prapanca, yang diakui UNESCO sebagai memori dunia. Ada kitab penting Kuntaramanawa yang konon ditulis Gadjah Mada. ada juga kitab Sutasoma yang ditulis Mpu Tantular yang menggambarkan toleransi yang kuat dalam keberagamaan yang terkenal dengan kalimat "Bhineka Tunggal Ika Tan Hana Dharma Mangruwa". Setelah Majapahit runtuh, berkembanglah pengaruh Islam. Kondisi ini juga mempengaruhi tradisi penulisan, yang bergeser ke tradisi penulisan kitab-kitab suluk seperti Suluk Sukrasa, Suluk Wujil, Malang Semirang, dan juga menyebabkan tradisi penulisan bergeser ke pesisir-pesisir. Sebagaimana dikatakan Widarmanto (2013:96), "mata rantai" penulisan sastra seperti itu menunjukkan bahwa kehadiran sastra Indonesia sastrawan Jawa Timur tidaklah lahir secara "tiba-tiba"; ada latar sejarah atau tradisi penulisan yang kuat, panjang, dan penting yang mendasari lahirnya karyakarya sastra Indonesia sastrawan Jawa Timur.

Beberapa sastrawan Jawa Timur yang menulis sastra Indonesia, di antaranya: Budi Darma, Suripan Sadi Hutomo, Suparto Brata, Akhudiat, Aming Aminoedin, M. Shoim Anwar, D. Zawawi Imron, Rusdi-Zaki, Beni Setia, Sirikit Syah, Beni Setia, Viddy AD Daery, S. Yoga, Luthfi Rachman, Muhammad Ali, Tengsoe Tjahjono, Tjahjono Widarmanto, Tjahjono Widiyanto, Herry Lamongan, Mashuri, Indra Tjahyadi, W. Haryanto, Denny Tri
Aryanti, S. Jai, F. Aziz Manna, dan sederet nama lainnya yang terus tumbuh dari masa ke masa - baik di Surabaya maupun di daerah-daerah Jawa Timur.

Selain sastrawan dan karyanya, di Jawa Timur juga banyak tumbuh dan berkembang komunitas sastra dan kelompok teater. Komunitas sastra ini sering berpentas dan menghasilkan naskah dramanamun hanya sedikit naskah yang terdokumentasi. Beberapa komunitas sastra Indonesia yang tercatat, di antaranya: FASS (Forum Apresiasi Sastra Surabaya), Forasamo (Forum Apresiasi Sastra Mojokerto), Komunitas Sastra Teater Persada (Ngawi), Komunitas BMS (Bengkel Muda Surabaya), Kostela (Komunitas Sastra dan Teater Lamongan), Komunitas Sastra Pesantren Al-Amien (Sumenep), Komunitas Sastra dan Teater Gapus (Fakultas Ilmu Budaya Unair, Surabaya), Komunitas Kalimas (Unesa, Surabaya) Forum Seni Sastra Luar Pagar (Unair Surabaya), dan FSBS (Forum Sastra Bersama, Surabaya). Peta sastra yang terkait dengan sastrawan dan komunitas itu belum pernah diungkap, sehingga tidak diketahui di daerahdaerah seperti Jawa Timur ada kegairahan beraktivitas dan berproduktivitas sastra Indonesia. Karya-karya itu sampai saat ini belum dikenal masyarakat pembaca nasional dan internasional. Kondisi sastra dan penciptaan sastra di Jawa Timur yang terkait sastrawan dan komunitasnya itu penting dipetakan dan diungkap kekhasan karyanya.

Pentingnya masalah penelitian ini dikaji didasarkan atas tiga alasan. Pertama, guna memperoleh peta karya sastra Indonesia sastrawan Jawa Timur sejak awal hingga yang paling mutakhir. Kedua, guna tersedia data penting tentang karya sastra Indonesia sastrawan Jawa Timur. Ketiga, agar masyarakat pembaca mengenal karya sastra Indonesia karya sastrawan Jawa Timur dengan kekhasannya.

Dalam penelitian ini dimanfaatkan perspektif sosiologi sastra. Melalui per- 
spektif ini dilihat korelasi sastra dengan sastrawan dan masyarakatnya, dikaji seperti apa sastra tumbuh dan berkembang dalam masyarakat, serta kekhasan yang membedakan dengan sastra Indonesia yang diproduksi sastrawan pusat kota seperti Jakarta. Bagi Damono (1984) dan Swingewood (1972), sosiologi sastra merupakan satu paradigma yang dapat digunakan mengkaji karya sastra dalam keterkaitannya dengan dunia sastrawannya (sosiologi pengarang), dengan kondisi sosial yang melingkungi (mimetik), dan dengan pembaca sastra (sosiologi pembaca). Lebih tegas lagi Escaprit (2005) mengatakan, kajian sosiologi sastra dapat melibatkan banyak relasi (relasi dengan pengarang, zaman, masyarakat, dan pembacanya). Sejalan dengan pemikiran itu, Ratna (2003) dan Hall (1979) juga menyatakan, kajian sosiologi sastra pada hakikatnya merupakan sebuah paradigma yang membuka peluang bagi kajian-kajian lebih jauh berkait dengan sastra.

Secara teoretik, penelitian ini tidak mengarah pada model analisis umum sosiologi sastra, tetapi lebih terkonsentrasi memetakan pertumbuhan dan perkembangan sastra Indonesia di Jawa Timur dalam kaitan dengan sastrawan dan lingkungan sosialnya serta mengungkap kekhasan karya-karyanya.

\section{METODE PENELITIAN}

Metode yang digunakan dalam penelitian ini adalah kualitatif-tekstual. Dengan metode ini dapat dijelaskan tipologi, corak, dan genre sastra yang dianalisis. Dengan pendekatan sosiologi sastra, kajian ini mula-mula berorientasi memetakan sastra Indonesia sastrawan Jawa Timur; dan lebih lanjut dan komprehensif dapat diungkap kekhasan karya-karya sastra Indonesia yang diproduksi sastrawan Jawa Timur. Dikajinya objek sastra dalam keterkaitannya dengan sastrawan dan masyarakatnya, menjadi alasan digunakannya pendekatan ini. Strategi dokumentasi merupakan strategi yang dipandang representatif, karena strategi ini paling efektif digunakan menelusuri teks-teks sastra yang berupa buku, jurnal, majalah, koran, dan dokumen-dokumen terkait lainnya, di mana pun sumber informasi itu ada-baik pada lembaga, kelompok, atau pun individu.

Karya-karya sastra Indonesia yang dijadikan objek dan sekaligus diteliti adalah semua karya sastra Indonesia (baik berupa puisi, prosa, dan drama) yang diproduksi sastrawan Jawa Timur, daerah Surabaya ataupun daerah-daerah kabupaten Jawa Timur lainnya. Karya sastra Indonesia tersebut adalah karya sastra yang sudah dipublikasikan atau diterbitkan, baik oleh penerbit umum maupun penerbit khusus (seperti komunitas sastra, pusat studi, dan dewan kesenian).

\section{HASIL DAN PEMBAHASAN}

Selain Surabaya, daerah-daerah basis di Jawa Timur yang sastrawannya produktif berkarya adalah: Gresik, Banyuangi, Lamongan, Mojokerto, Ngawi, Madura, Sidoarjo, dan Malang. Berikut merupakan seluruh karya sastrawan Jawa Timur berdasarkan klasifikasi genrenya: prosa, puisi, dan teks drama.

\section{Peta Prosa Indonesia Karya Sastrawan Jawa Timur dan Kekhasannya}

Satu genre sastra Indonesia yang dominan ditulis sastrawan Jawa Timur adalah prosa. Karya-karya prosa itu dipublikasi dalam bentuk buku tunggal dan juga kumpulan karya, dipublikasi penerbit komunitas atau penerbit umum. Pada awalnya, diciptakan karya-karya prosa Indonesia para sastrawan Jawa Timur yang dihimpun sastrawan Suripan Sadi Hutomo pada tahun 1991, berjudul Cerita Pendek dari Surabaya, yang kemudian diterbitkan Dewan Kesenian Surabaya tahun 1991. Di dalam karya ini termuat lima belas cerpen karya sastrawan generasi awal sastra Indonesia. Keseluruhan 
cerpen yang terhimpun di dalamnya mengekspresikan kondisi sosial Surabaya pada masanya.

Terbit juga tahun 1993 kumpulan cerpen Limau Walikota karya sastrawan Shoim Anwar dan Imung Mulyanto diterbitkan oleh Penerbit Surabaya Post. Di dalam kumpulan cerpen ini terhimpun sejumlah 23 judul cerpen. Kemudian disusul dengan karya prosa (novel) Prosesi: Jiwa yang Terpenjara karya Zoya Erawati ditebitkan Penerbit Balai Pustaka, Jakarta, tahun 1999.

Karya berikutnya berupa kumpulan cerpen Bermula dari Tambi: 30 Cerita Pendek dari Jawa Timur Para Cerpenis Jawa Timur Surabaya 1999. Sebagaimana tampak dalam judul kumpulan cerpen ini, ada 30 cerpen yang terhimpun di dalamnya. Kemudian, ada novel Kerudung Santet Gandrung. Novel ini ditulis sastrawan, budayawan, dan sesepuh masyarakat Osing Banyuangi Hasnan Singodimaja, diterbitkan Penerbit Desantara Jakarta tahun 2003.

Kemudian Lan Fang menulis kumpulan cerpen Laki-laki yang Salah, diterbitkan Gramedia Pustaka Utama, Jakarta, tahun 2003. Satu hal yang menarik dalam buku ini adanya pembagian atau pengelompokan cerpen yang dibagi atas tiga, yakni: siang, malam, dan pagi. Terbit juga kemudian sebuah novel yang berjudul Derak-derak karya Zoya Erawati. Novel ini diterbitkan Penerbit Ombak, Yogyakarta, tahun 2005, dan terbagi dalam 22 bagian. Novel ini disajikan dengan gaya bercanda, namun mengisahkan suatu hal yang sangat penting bagi bangsa yakni jiwa-jiwa yang terbelah yang banyak dialami oleh para politikus di negeri ini.

Dalam peta selanjutnya, terbit novel $H u b b u$ karya Mashuri. Novel ini diterbitkan Penerbit ternama Gramedia Pustaka Utama, Jakarta, tahun 2006. Novel ini pernah memenangi Juara I Sayembara Novel DKJ 2006. Dalam kompetisi, novel ini berkompetisi dengan 249 karya dengan tiga juri, yang akhirnya memenangkannya, karena menurut Juri yang diketuai Ahmad Tohari, novel ini dipandang sebagai karya yang sangat utuh dan padu ceritanya.

Setelah novel Hubbu, terbit juga kemudian novel Pecinan Kota Malang Ratna Indraswati Ibrahim. Karya ini diterbitkan oleh Hunan Publishing, Malang, 2008. Novel ini berkisah tentang masyarakat Cina yang ada di Indonesia, khususnya Malang, yang tidak hanya datang untuk tujuan ekonomi tetapi juga siar Islam.

Shoim Anwar menulis himpunan cerita pendek Asap Rokok dan Jilbab Santri. Kumpulan cerpen ini diterbitkan Penerbit Jaring Pena, Surabaya, tahun 2009. Menurut beberapa tokoh yakni Taufiq Ismail, Sunaryono Basuki, Setya Yuwono, Maman S. Mahayana, dan D. Zamawi Imron, cerpen-cerpen ini merespons berbagai persoalan yang ada dalam masyarakat, berkisah tentang kaum marjinal (wong cilik) dan juga menyajikan pergulatan batiniah.

Terbit pula novel Siti Surabaya karya Aziz Manna. Novel ini diterbitkan Penerbit Diamond Surabaya tahun 2010. Karya prosa kedua belas, merupakan kumpulan cerpen pilihan Festival Seni Surabaya Imajinasi tentang Kata. Cerpen-cerpen ini ditulis para pengarang Surabaya, diterbitkan Festival Seni Surabaya tahun 2010. Di dalam kumpulan cerpen ini terhimpun 10 cerpen pilihan.

Lan Fang kembali menulis novel Ciuman di Bawah Hujan. Novel ini diterbitkan Gramedia Pustaka Utama, Jakarta tahun 2010, dan merupakan pengembangan cerita novelet 1001 Hari di Hong Kong, yang pernah memenangkan penghargaan cerita bersambung Femina tahun 2005. Di dalam novel ini sastrawan berkisah tentang Sang Maha yang tidak berada di awang-awang, tetapi dalam kehidupan keseharian yang dekat dengan kita.

Seorang sastrawan, Beni Setia, menerbitkan kumpulan cerpen Cerita Singkat dan 
Tafsir Politik. Kumpulan cerpen ini diterbitkan Festival Seni Surabaya pada tahun 2010. Buku kumpulan cerpen - sastrawan dari Caruban-Madiun-ini memuat 15 judul cerpen. Ada juga sastrawan Sirikit Syah yang menyebut karyanya sebagai human interest, namun karya ini sebenarnya berasal dari cerpen yang pernah dipublikasi dalam berbagai media massa, yakni berjudul Harga, diterbitkan Penerbit Gorong-gotong Surabaya tahun 2010.

Lan Fang kembali menulis novel berikutnya Reinkarnasi. Novel ini diterbitkan Kompas, Jakarta, tahun 2012, terbagi menjadi lima bagian, dan mengisahkan tentang kondisi rasialisme yang merebak terutama kepada warga keturunan Cina di zaman pemerintahan Soeharto. Kondisi ini dialami sastrawannya sendiri, yang selalu dicap Cina meskipun ia sudah berusaha bergaul dengan pribumi. Ekspresi kebencian sastrawan pada rasialisme terlukiskan dalam karyanya.

Selain karyanya itu, Lan Fang juga menulis novel Fai Yin. Novel ini diterbitkan Gramedia Pustaka Utama, Jakarta, tahun 2012; merupakan kelanjutan dari novel Reinkarnasi, yang di dalam kisahnya masih "menghembuskan nafas" yang sama yakni ideologi dan romantismebaik ideologi terhadap pengkotak-kotakan etnis maupun romantisme terhadap "cinta" itu sendiri. Kemudian, disusul lagi dengan karya novel Perempuan Kembang Jepun. Novel ini diterbitkan Penerbit Gramedia Pustaka Utama, Jakarta, tahun 2012. Buku setebal 284 halaman ini tidak hanya berkisah tentang uang dan seks, tetapi juga cinta dan kebersamaan, dialah "Sang Hidup" yang memberi arti. Novel ini berkisah dengan latar belakang kawasan Kembang Jepun di Surabaya pada tahun 1940-an. Novel yang Lelakon, merupakan karya Lan Fang yang melengkapi karyakarya lainnya itu, diterbitkan Gramedia Pustaka Utama, Jakarta, tahun 2012.

Selain karya Lan Fang, terbit pula novel Nawi BKL Inah karya Antariksawan
Yusuf dan Hari Z. Noor Republika, Jakarta, tahun 2013. Novel ini berkisah tentang bagian Indonesia yang bernama Osing (ujung timur daerah Jawa Timur), yang dikisahkan dalam bentuk cerita, tutur, gaya, budaya, dan bahasa Osing. Kemudian, ada juga novel Kumara: Hikayat Sang Kekasih karya S. Jai. Novel etnografis ini diterbitkan Dewan Kesenian Jawa Timur, Surabaya, tahun 2013. Novel ini merupakan satu karya sastra terpilih dalam program "Jawa Timur Bicara" yang dicanangkan Dewan Kesenian Jawa Timur, yang kisahnya mengambil dari kisah kekuasaan danyang desa. Menurut sastrawannya, dalam tradisi $\mathrm{Hindu}, \mathrm{Ku}-$ mara adalah Sanghyang Kumara-Dewa Pelindung Bayi-salah satu putera Dewa Siwa. Novel ini memiliki kekuatan daya ucap tradisi sejarah lokal Jawa Timur, yang di antaranya dapat disimak dalam deskripsi novel berikut:

"Ketika rombongan Maharaja Linggabuana dan putrinya tiba di Bubat, konon dekat Trowulan, dikawal sedikit pasukan, oleh Patih Gajah Mada diartikan Dyah Pitaloka sebagai taklukan Majapahit.

Pihak para tamu itupun menolak untuk berbuat demikian. Perang tak bisa dihindari dan binasalah seluruh darah Sunda di Bubat.

Mitos itu konon bermula dari sikap Pangeran Niskalawastu Kancana, adik Putri Dyah Pitaloka, memutuskan hubungan diplomatik dengan Majapahit, bahkan terhadap semua nyang berbau Jawa. Termasuk perkawinan." (Jai, 2013:87)

Sastrawan Ngawi bernama Tjahyono Widianto menulis kumpulan cerpen Cakil, dan diterbitkan Pustaka Puitika Surabaya, tahun 2014. Karya ini merupakan karya terbaru, yang memuat 16 judul cerpen. Berdasarkan hasil penelusuran pustaka yang telah dilakukan, selain ditemukan karya-karya prosa Indonesia yang dipublikasi Penerbit Umum, ada juga yang diterbitkan Penerbit Komunitas yang ter- 
dapat di berbagai daerah, terutama yang ditemukan adalah daerah Lamongan dan Banyuangi.

Dari daerah Lamongan terbit dua karya yang keduanya merupakan kumpulan cerpen Aku Tak Rela Ia Mati Terhormat: Antologi Cerpen dan Mawar Putih: Antologi Kumpulan Cerpen. Dari Banyuangi juga terbit dua karya novel. Novel pertama, yang lebih berupa novel sejarah Berdirinya Kerajaan Macan Putih II: Sebuah Novel Sejarah; kedua, novel Akademos, yang ditulis Imamuddin, diterbitkan Penerbit Komunitas (tanpa nama) pada tahun (tth).

Selanjutnya terbit karya Aku Tak Rela Ia Mati Terhormat: Antologi Cerpen dan Mawar Putih: Antologi Kumpulan Cerpen, ditulis sastrawan AS Sambawi. Karya ini diterbitkan Penerbit Rumah Pustaka, Lamongan, tahun 2005, dan memuat 12 karya cerpen. Disusul dengan terbitnya sebuah kumpulan cerpen Mawar Putih: Antologi Cerpen Pelajar M.A. Matholi'ul Anwa, memuat 13 belas cerpen. Sebagaimana terbaca dalam judul buku kumpulan cerpen ini, sastrawannya adalah para pelajar yang relatif baru menulis karya sastra - sebagai sastrawan pemula.

Karya novel Berdirinya Kerajaan Macan Putih II: Sebuah Novel Sejarah ditulis sastrawan Armaya, dan diterbitkan Pusat Studi Budaya Banyuangi, Banyuangi, tahun 2010. Novel ini berkisah tentang Kerajaan Macanputih yang baru lepas dari Kerajaan Mataram. Di dalamnya dikisahkan seorang raja yang harus membangun kerajaannya, sebagai kerajaan yang muda. Namun di tengah usahanya itu sang raja sakit dan sakitnya makin parah. Novel ini berkisah tentang daerah Banyuangi yang dulunya bernama Blambangan. Karya ini disusul juga dengan terbitnya novel berjudul Akademos karya Imamuddin diterbitkan penerbit komunitas di Banyuangi. Novel ini terbagi dalam dua belas bagian, berkisah tentang kehidupan di Banyuangi.

\section{Peta Puisi Indonesia Karya Sastrawan Jawa Timur dan Kekhasannya}

Selain dominannya karya prosa Indonesia terutama cerpen, sastrawan Jawa Timur juga banyak menulis puisi Indonesia. Ini berarti, sastrawan Jawa Timur juga kuat dalam penulisan genre puisi. Namun, tumbuhnya puisi yang cukup dominan, tidak diimbangi kritik sastra. Ini seperti yang kerapkali dikeluhkan para sastrawan bahwa jumlah kritikus tidak berimbang dengan karya-karya yang dilahirkan. Diketahui juga secara kuantitatif, jumlah karya-karya puisi Indonesia dan penyair Jawa Timur lebih banyak ketimbang jenis lainnya yakni prosa, drama, apalagi kritik sastra. Banyaknya genre puisi tidak saja yang diterbitkan penerbit umum, tetapi juga penerbit komunitas yang ada di seluruh daerah di Jawa Timur.

Dengan peta sastra semacam itu, sampai pada batas tahun 2000-an, Jawa Timur masih dapat diberi sebutan "daerah puisi" atau "daerah penyair". Puisi-puisi yang diciptakannya pun begitu khas mencerminkan kedaerahan (etnografis)-nya.

Berdasarkan penelitian, buku karya puisi Indonesiaperta, a karya sastrawan Jawa Timur adalah sebuah kumpulan puisi yang berjudul Antologi Puisi 25 Penyair Surabaya yang dieditori Suripan Sadi Hutomo (alm.) dkk. Buku kumpulan puisi ini diterbitkan Dewan Kesenian Surabaya, tahun 1975. Karya puisi Indonesia ini disusul dengan diterbitkannya kumpulan puisi Semangat Tanjung Perak. Puisi-puisi dalam kumpulan ini ditulis Para Penyair Surabaya, dan diterbitkan Penerbit Mandiri, Surabaya, tahun 1992. Di dalam buku puisi ini ada 25 penyair yang menuliskan puisi-puisinya. Disusul dengan terbitnya buku kumpulan puisi 34 penyair dengan judul Doa Tangan-tangan: Kumpulan Puisi. Kumpulan puisi ini ditulis Para Penyair Surabaya, dan diterbitkan Bengkel Muda Surabaya, tahun 2006.

Diketahui juga kumpulan puisi bunga rampai yang berjudul Rumah Pasir: An- 
tologi Puisi. Buku Kumpulan puisi ini ditulis tiga penyair dan kuratori oleh Arief B. Prasetyo (ed.) dan diterbitkan Festival Seni Surabaya Surabaya, tahun 2007. Lalu, Mardi Luhung, seorang penyair dari Gresik menulis kumpulan puisi penyair tunggal Ciumam Bibirku yang Kelabu. Karya ini diterbitkan Dewan Kesenian Jawa Timur, di dalam kumpulan puisi ini terhimpun 68 judul puisi.

Terbit juga bunga rampai puisi yang terhimpun dalam buku Pesta Penyair: Antologi Puisi Jawa Timur. Buku ini diedit Ribut Wiyoto, dkk., dan diterbitkan Dewan Kesenian Surabaya, Surabaya, tahun 2009. Di dalam buku ini terhimpun puisi-puisi penyair Jawa Timur. Tengsoe Tjahyono menulis kumpulan puisi yang berjudul Salam Mempelai: Kumpulan Puisi. Buku ini diterbitkan Penerbit Pustaka Ilalang, Lamongan, tahun 2010. Kumpulan puisi ini dibagi dalam tiga labirin, yakni: (1) Labirin Mata Angin, (2) Labirin Perjalanan, dan (3) Labirin Kabut. Masingmasing labirin itu juga mencakup banyak puisi.

Indra Tjahyadi, dinobatkan sebagai penyair terbaik tahun 2013 karena menulis kumpulan puisi tunggalnya berjudul Syair Pemanggul Mayat. Buku kumpulan puisi ini diterbitkan Festival Seni Surabaya, Surabaya, tahun 2011. Puisi-puisinya yang surrealis memang tidak mengeksplisitkan lokalitas, tetapi inspirasinya tidak lepas dari lokalitas Jawa Timur yang diolahnya dalam keketatan diksi; sebagian dapat disimak dalam penggalan bait sajaknya "Takdir Ledakan Peluru": "//... Gerimis kuyup dedaun mengundang jerit hantuhantu. Sembari tertidur, kubiarkan tetek bulan kuyu, berkerontangan di sebalik bantalku. Raib matahari, juga terik yang ubah pejalan jadi apak bau peluh!//" (Tjahjadi, 2011:136). Disusul karya penyair senior bernama Akhudiat yang menulis kumpulan puisi Pohon Bernyanyi: Kumpulan Puisi 1973-2010. Buku kumpulan ini diterbitkan Penerbit YAA, Surabaya, tahun 2012.
Dari daerah Malang terbit kumpulan puisi Sulfatara: Pelangi Sastra Malang dalam Puisi. Buku kumpulan ini merupakan buku bunga rampai Para Penyair Malang, dan diterbitkan Penerbit Resist bekerjasama dengan Pelangi Sastra Malang tahun 2012. Ada 16 penyair yang menuliskan puisi-puisinya dalam buku bunga rampai puisi ini. Ada juga kumpulan puisi yang ditulis oleh Puisi Indonesia kedua belas, merupakan kumpulan puisi penyair tunggal Tengsoe Tjahjono Yang Bertamu adalah Ilham (Kumpulan Puisi). Buku Kumpulan puisi ini diterbitkan Sanggar Kalimas Surabaya tahun 2013. Dalam sebuah puisinya "Tambak-tambak Membeku", Tjahjono tampak mengungkapkan suasana lokal sekitar tambak yang banyak ada di Jawa Timur dalam kondisi yang mengering akibat cuaca alam yang acapkali kurang bersahabat: "/ tambak kiri-nanan itu, meluas bagai tanah lapang. beku/ jangan kau cari lumpur pasir, tanah bergambut, akar-akar bakau/ air telah dibiarkan kering oleh matahari// (Tjahjono, 2013:90). Lalu, terbit juga buku kumpulan puisi tunggal berjudul Munajat Buaya Darat: Kitab Puisi karya Mashuri, dan diterbitkan Galang Press Yogyakarta tahun 2010.

F. Aziz Manna, kembali menerbitkan kumpulan puisi penyair tunggal Tanggulendut yang diterbitkan Dewan Kesenian Surabaya Tahun 2013. Di dalam kumpulan puisi ini termuat 37 judul puisi-puisi naratif dengan tematik tentang korban lumpur Lapindo. Puisi-puisi yang terhimpun di dalamnya mengungkap kondisi sosial tentang duka derita yang begitu getir dialami masyarakat sekitar musibah lumpur Lapindo, yang kehilangan rumah, tanah leluhur, dan tercerai-berainya sanak-saudara. Berikut dapat disimak penggalan kutipan satu puisinya "Tangglendut I":

//di timur tanggulangin, cinta meleleh, kau talak kami seperti rumah yang tenggelam. Betapa hancur jiwa kami, 
sunyi menanggul air mata yang mencucur tak sudah-sudah... rerumput merintih di hati kami... penantian kami mengeras melebihi kutuk malin kundang atau pepatung heligan// (Manna, 2013:7).

Hampir seluruh puisi karya Aziz Manna mengekspresikan duka derita yang dialami masyarakat sekitar daerah lumpur Lapindo. Soal ini diekspresikan secara intens, karena Manna sendiri memang berasal dari Sidoarjo, kesedihannya begitu dihayati, karena Sidoarjo itu adalah daerah kelahirannya.

Dari tangan penyair Malang, Joko Saryono, terbit kumpulan puisi Arung Diri: Kitab Puisi, diterbitkan Penerbit Ditya Media, Malang, tahun 2013. Di dalamnya, dimuat puisi-puisi yang dikelompokkan menjadi tiga subjudul, yakni: "Arung Cerita", "Arung Jiwa", dan "Arung Raga". Dalam puisi-puisinya ini, sangat kental diwarnai kedalaman penghayatan filsafat budaya Jawa (khususnya wayang Jawa). Ia menggali nilai klasik yang masih perlu dikobarkan saat ini, karena dipandang masih relevan. Tegaknya bangsa trntu tetap memerlukan semangat patriotisme sebagaimana yang ditunjukkan tokoh kastria Kumbakarna dari Alengka dalam puisi "Kematian Indah Ksatria" :

"//Aku Kumbakarna, ksatria negeri Alengka/, /bukan kehidupan kucari, bukan kematian kuhindari/,/kedaulatan negeri harus kubela - kendati bertaruh nyawa/, /martabat negara harus kujaga-meskipun maut menemui//". (Saryono, 2012:18)

Puisi-puisi lainnya juga mengekspresikan renungan-renungan filsafat hidup yang serupa yang diperlukan manusia untuk menjalani kehidupan yang harmonis. Penguasaannya yang kuat atas filosofi wayang, disertai kepekaannya melihat problematika kehidupan sekitar, terpadu sangat baik, sehingga puisi-puisi yang disajikan menjadi enak dibaca dan mem- beri sentuhan rohani. Selanjutnya dapat disimak dalam petikan bait berikut:

"//Benar, benar, aku anak Sukesi dan Wisrawa/, yang telah gagal mengelola gelak asmara/, /hingga mereka induk segala angkara dan petaka/,/Bagaimana mungkin aku harus menyatakan dusta?/, /padahal kebenaran dan kebajikan bagiku mahkota// (Saryono, 2012:23)

Diterbitkannya kumpulan puisi Janturan: Kumpulan Puisi kaya Tjahyono Widiyanto oleh Penerbit Spirit Karawaci tahun 2014, yang memuat 34 judul puisi, menambah kelengkapan puisi-puisi sastrawan Jawa Timur sebagai puisi yang memiliki kekuatan dalam pengucapan kearifan lokalnya. Puisi-puisi yang ditulisnya kendatipun tak mengungkap secara eksplisit kondisi lokal, namun dalam bait-baitnya yang puitik sangat terasa bagaimana latar lokal yang begitu kuat mengaliri puisinya:

"//sejumput tembang sempurna merajut bunyi menjadi sunyi/, /seteguk sajak membangkitkan jejak seperti bayang-bayang raksasa telanjang/, / sealir syair mengalir merembesi rembulan memahat syahwat sepasang kekasih/,/lintang-lintang gemetar tak kuasa meraungkan lanskap kematian/" (Widarmanto, 2011:10)

Penerbit komunitas juga menerbitkan buku-buku genre puisi. Antologi puisi Menara Tujuh Belas: Antologi Puisi Banyuangi, diterbitkan Pusat Studi Budaya Banyuangi, tahun 2002, yang memuat 17 penyair. Karya puisi Indonesia ini disusul dengan terbitnya buku antologi puisi Syahadat Sukma: Kumpulan Puisi, yang ditulis penyair Ifoel Mundzuk dan diterbitkan Penerbit Pustaka Pujangga Lamongan, tahun 2004. Berikut terbit antologi puisi Banyuangi ditulis 28 penyair dan diterbitkan JP Press Banyuangi, tahun 2004. Buku ini menarik, karena menggunakan tiga bahasa sekaligus (Indonesia, Jawa, 
dan Inggris). Penyair Decky Irmawan misalnya menulis puisi "Pesta Nelayan" (Indonesia), "In The Land of Blambangan" (Inggris), dan penyair Eko Budi Setianto menulis "Suwuk 1" (Jawa). Menariknya, meskipun berbeda dalam bahasa, para penyair ini memiliki pijakan kondisi sosial budaya yang kuat, yakni Banyuangi. Berbagai kearifan lokal diungkap dalam puisi-puisinya. Berikut adalah latar lokal pesisir Banyuangi yang menonjol diungkap dalam puisinya: "/Perahu-perahu elok berdandan/, /Umbul dan pataka dibentang...//Disudut lain/ perempuan separuh baya termangu/bertanya-tanya/ pukul berapa sajian dihantarkan?//" (Imanuddin, 2004:37)

Karya puisi Indonesia Setetes Kota Sarung: Antologi Puisi merupakan karya yang ditulis para penyair Sumenep (Madura), dan diterbitkan Sanggar Andalas PP Annugayal Daerah Guluk-guluk Sumenep, Madura 2007. Ada delapan penyair yang menulis dalam kumpulan puisi ini. Ada juga antologi banyak pengarang Kamaskastra: Antologi Puisi dan Prosa. Karya ini ditulis oleh 29 Penyair Lamongan, dan diterbitkan La Rose, Lamongan tahun 2009.

Karya kumpulan puisi Indonesia Cahaya Nun: Antologi Puisi, yang ditulis 17 penyair Sumenep diterbitkan Sanggar Andalas PP Annugayal Daerah Gulukguluk Sumenep, Madura tahun 2011. Selanjutnya, terbit antologi puisi Nyanyi Kehidupan: Puisi-puisi Airmaya, ditulis penyair Banyuangi, Armaya, dan diterbitkan Pusat Studi Budaya Banyuangi, Banyuangi, tahun 2011. Di dalam buku antologi ini terdapat 30 puisi. Karya puisi Indonesia lainnya yang terbit adalah kumpulan puisi berjudul Waktu yang Hilang Tertinggal: Kumpulan Puisi. Dalam buku kumpulan puisi ini ada banyak penyair muda yang menulis di dalamnya, serta diedit Saiful Anan Assaibani (ed.) dan diterbitkan Buku Sodra di Lamongan tahun 2013.

\section{Peta Teks Drama Indonesia Karya Sas- trawan Jawa Timur}

Genre sastra drama Indonesia yang ditulis sastrawan Jawa Timur hanya sedikit ditemukan. Dalam bentuk buku hanya ada satu buku yang terdokumentasi, yakni: Orde Mimpi: Drama Pilihan 19942007. Dalam buku kumpulan drama ini termuat 14 naskah drama. Keempat belas judul drama tersebut adalah: (1) "Tentang Salah Paham Generasi", (2) "Biografi Kursi Tua", (3) "Luka Panjang Karena Perang", (4) "Monolog Peperangan", (5) "Korupsi yang Berurat dan Berakar", (6) "Retorika Lelaki Senja", (7) "Gagal Melahirkan Generasi Baru", (8) "Orde Mimpi", (9) "Rumitnya Menyelesaikan Masalah", (10) "Orang-orang Bawah Tanah", (11) "Dari Kacau ke Kacau", (12) “Terompet Senjakala", (13) "Sebuah Adaptasi dari Novel Bumi Manusia”, dan (14) "Hikaray Perlawanan Sanikem: Nyai Ontosoroh".

Apabila teks drama yang dipublikasi umum ditemukan terhimpun hanya dalam satu kumpulan teks drama, maka yang dipublikasi komunitas belum ada ditemukan yang terpublikasi. Komunitaskomunitas sastra di Jawa Timur tampaknya belum ada yang berinsiatif menerbitkan teks-teksnya, kendatipun - dengan sangat meyakinkan-di masing-masing komunitas sastra dan teater yang ada pasti memiliki atau memproduksi teks drama juga. Hanya saja komunitas-komnitas itu belum menerbitkan teks-teks yang diproduksi menjadi dokumen, mungkin karena kurang ada tradisi pendokumentasian karya drama.

Dalam khasanah sastra Indonesia, genre yang sampai saat ini diakui hanyalah: puisi, prosa, dan drama. Kritik sastra belum diakui. Namun, dalam bagian ini, kritik sastra (esai sastra) juga diungkap di sini untuk memberikan peta sastra sastrawan Jawa Timur yang lebih. Berkait dengan kritik sastra, ditemukan hanya sedikit hasil kritik sastra (esai sastra) yang pernah ditulis dan didokumentasi 
berkait dengan pembahasan karya-karya sastra Indonesia karya sastrawan Jawa Timur. Karya kritik sastra Indonesia yang dipublikasi umum di Jawa Timur relatif terbatas. Hanya ditemukan ada satu karya yang berhasil diperoleh (yang pernah ada dan yang terdokumentasi). Buku yang dikuratori Yusril Fajar (Malang) ini merupakan buku satu-satunya yang ditemukan sebagai buku kritik sastra (esai sastra), dan juga sebagai buku yang baru terbit tahun 2014. Ini menunjukkan bahwa pertumbuhan dan produksi karya sastra Indonesia tidak berimbang dengan hasil kritik sastranya.

Di dalam buku yang diterbitkan Dewan Kesenian Jawa Timur ini, termuat ada beberapa penulis (kritikus/esai) yang menuliskan dalam karyanya, dan beberapa di antaranya sekaligus adalah sastrawan Jawa Timur. Beberapa penulis tersebut adalah Arif Bagus Prasetyo dalam kritiknya "Sastra Indonesia Mutakhir Jawa Timur", Beni Setia dalam tulisannya "Tiga Cerpenis Jawa Timur", Denny Mizhar dalam tulisannya "Membaca Suara Sunyi Rose Widianingsih", Ikwan Setiawan dalam tulisannya "Meng-Investasi Lokalitas: Narasi dan Wacana Sastrawi di Jawa Timur", Imam Muhtarom dalam tulisannya "Kenyatan Sosial dalam Cerpen Jawa Timur", K.Y. Karnanta dalam tulisannya "Lan Fang dan Cerpen Jawa Timur", Ribut Wiyoto dalam tulisannya "Selayang pandang Kepenyairan Jawa Timur", M. Shoim Anwar dalam tulisannya "Sastra Indonesia dan Pertarungan Ideologis", Sony Karsono dalam tulisannya "On Some Themes in Budi Darma's Rafilus", Suryadi Kurniawan dalam tulisannya "Representasi Surabaya dalam Dua Antologi Puisi", Tjahyono Widarmanto dalam tulisannya "Tradisi Sastra Jawa Timur", Tjahyono Widijanto dalam tulisannya "Perbenturan Budaya Pesisir dan Pendalaman Tinjauan atas Sajak-sajak Mardi Luhung", Wawan Eko Yulianto dalam tulisannya "Hubbu Seolah Bilang: "Aja Golek mMatengan
Ae, Cuk!", Yulitin Sungkowati dalam tulisannya: Memetakan Komunitas Sastra Indonesia di Jawa Timur".

Selain buku kritik sastra tersebut, di Banyuangi terbit satu buku esai. Tulisantulisan yang terdapat di dalamnya cenderung berupa apresiasi dan belum pada kritik sastra. Buku ini ditulis para penulis dari Banyuangi Gandroeng dan Banyuangi, diedit Taufiq WR Hidayat, merangkum banyak tulisan, diterbitkan Pusat Studi Budaya Banyuangi di Banyuangi tahun 2009.

Berdasarkan kajian tersebut, dapat dikatakan peta sastra Indonesia sastrawan Jawa Timur lebih didominasi penciptaan prosa (cerpen) dan puisi. Dari data kuantitatif yang ditemukan, buku prosa, ada 22 judul buku yang diterbitkan oleh penerbit umum dan 4 judul yang diterbitkan penerbit komunitas. Buku puisi, ada 17 judul buku puisi yang diterbitkan penerbit umum dan 8 judul buku yang diterbitkan oleh penerbit komunitas. Adapun jenis lainnya, yakni drama hanya ditemukan 1 judul naskah yang diterbitkan penerbit umum (Dewan Kesenian Jawa Timur). Diketahui juga, tidak semua daerah di Jawa Timur menonjol kreativitas dan produktivitas sastranya. Diketahui ada sepuluh daerah kantong sastra saja, yakni: Lamongan, Gresik, Banyuangi, Sumenep, Sidoarjo, Nganjuk, Malang, Mojokerto, Sidoarjo, dan Surabaya. Daerah-daerah itu dapat dkatakan sebagai kantong-kantong sastrawan sastra Indonesia, khususnya yang menulis jenis cerpen dan puisi.

\section{SIMPULAN}

Pertama, dalam penciptaan sastra Indonesia, sastrawan Jawa Timur ada yang menulis genre prosa, puisi, serta sedikit teks drama dan kritik sastra. Karya-karya ditulis dalam bentuk buku, yang diterbitkan penerbit umum dan komunitas (yang tersebar di Jawa Timur). Diketahui juga, daerah-daerah yang menjadi kantong produktivitas sastra Indonesia di 
Jawa Timur adalah: Lamongan, Gresik, Banyuangi, Sumenep, Sidoarjo, Nganjuk, Malang, Mojokerto, Sidoarjo, dan Surabaya ) .

Kedua, dalam peta sastra Indonesia karya sastrawan Jawa Timur, diketahui lebih didominasi penciptaan "prosa (cerpen)" dan "puisi". Ini menunjukkan bahwa sastrawan Jawa Timur dalam menulis karya sastra Indonesia lebih banyak menekuni dua jenis prosa (cerpen) dan puisi. Maka itu, Jawa Timur dapat disebut sebagai "daerah puisi dan cerpen".

Ketiga, berdasarkan analisis keseluruhan karya sastra Indonesia yang ditulis sastrawan Jawa Timur, sastra Indonesia ciptaan sasatrawan ini memiliki kekhasan berpijak pada tradisi, budaya, lingkungan alam, dan karakter Jawa Timur. Dalam penciptaan karya, ada sastrawan yang mengungkapkan dalam aliran realis, romantis, dan bahkan ada yang surrealis. Kekhasan karya-karya sastrawan Jawa Timur ini dapat dilihat dari kearifan lokal dengan subkulturnya yang mewarnai karya-karya sastrawan Jawa Timur, yang membedakan dengan sastra Indonesia pada umumnya.

\section{UCAPAN TERIMA KASIH}

Melalui artikel ini, kami menyampaikan ucapan terima kasih kepada semua pihak yang telah berperan serta dalam penelitian dan penerbitan artikel ini. Artikel ini ditulis dari hasil penelitian Hibah Kompetensi Tahun Anggaran 2014 dengan judul "Etnopuitika Karya Sastra Indonesia Sastrawan Jawa Timur: Kajian Holistik Sosiologi Sastra". Pertama, kami menyampaikan ucapan terima kasih kepada Direktur DP2M DIKTI yang telah mendanai penelitian Hikom ini. Kedua, kami menyampaikan ucapan terima kasih kepada Rektor Universitas Airlangga lewat Ketua LPPM Universitas Airlangga yang telah memasilitasi penelitian ini. Ketiga, ucapan terima kasih kami sampaikan kepada semua pihak pemberi data dan informasi. Keempat, tentunya kami menyampaikan ucapan terima kasih kepada redaktur Litera: Jurnal Bahasa, Sastra, dan Pengajarannya yang menerima dan menerbitkan artikel ini.

\section{DAFTAR PUSTAKA}

Akhudiat. 2012. Pohon Bernyanyi: Kumpulan Puisi 1973-2010. Surabaya: YAA.

Anwar, Shoim dan Imung Mulyanto (ed.). 1993. Limau Walikota: Kumpulan Cerita Pendek Surabaya Post, Cet I. Surabaya: Surabaya Post.

Anwar, Shoim dan Imung Mulyanto (ed.). 1999. Bermula dari Tambi: 30 Cerita Pendek dari Jawa Timur. Surabaya: Dewan Kesenian Jawa Timur.

Anwar, Shoim. 2009. Asap Rokok di Jilbab Santri. Surabaya: Jaring Pena.

Anwar, Shoim, Widodo Basuki, dan Imam Muhtarom. 2010. Imajinasi tentang Kota: 10 Cerpen Pilihan Festival Seni Surabaya 2010. Surabaya: Festival Seni Surabaya 2010.

Armaya. 2011. Nyanyi Kehidupan: Puisipuisi. Banyuangi: Pusat Studi Budaya Banyuangi.

Assyaibani, Saifuf Anam (ed.). 2009. Kamashastra: Sebuah Antologi. Lamongan: La Rose.

Damono, Sapardi Djoko. 2014. Sosiologi Sastra: Sebuah Pengantar. Jakarta: P4B

Escaprit, Robert. 2005. Sosiologi Sastra. Jakarta: Yayasan Obor Indonesia.

Fang, Lan. 2005. Laki-laki yang Salah. Jakarta: Gramedia Pustaka Utama.

Fang, Lan. 2010. Ciuman di Bawah Hujan. Jakarta: Gramedia Pustaka Utama.

Fang, Lan. 2012a. Reinkarnasi. Jakarta: Gramedia Pustaka Utama.

Fang, Lan. 2012b. Pai Yin. Jakarta: Gramedia Pustaka Utama.

Fang, Lan. 2012c. Perempuan Kembang Jepun. Jakarta: Gramedia Pustaka Utama.

Fang, Lan. 2012d. Lelakon. Jakarta: Gramedia Pustaka Utama. 
Hall, John. 1979. The Theory of Sociology Literature. London and New York: Longman.

Hasnan, Singodimaja. Kerudung Santet Gandrung. Jakarta: Desantara

Herawati, Zoya. 2005. Derak-Derak. Yogyakarta: Ombak.

Herawati, Zoya. 1999. Prosesi (Jiwa yang Terpenjara). Jakarta: Balai Pustaka.

Hidayat, Taufiq (ed.). 2009. Gandroeng dan Banyuangi, Banyuangi: Pusat Studi Budaya.

Hutomo, Suripan Sadi, dkk. (ed.). Antologi Puisi 25 Penyair Surabaya. Surabaya: Dewan Kesenian Surabaya.

Hutomo, Suripan Sadi, dkk. (ed.). 1991. Cerita Pendek dari Surabaya. Surabaya: Dewan Kesenian Jawa Timur.

Ibrahim, Ratna Indraswari. 2008. Pecinan Kota Malang. Malang: Guman Publishing.

Ilahi, Shohifur Ridho. 2013. Rokat Perahu Mawar. Surabaya: Dewan Kesenian Jawa Timur.

Imamuddin SA. Tth. Akademos: Puisi 30 Penyair. Banyuangi: tanpa Penerbit.

Giryadi, R. 2009. Orde Mimpi (Kumpulan Naskah Drama 1994 -2007). Surabaya: Dewan Kesenian Jawa Timur.

Jai, S. 2013. Kumara: Hikayat Sang Kekasih. Surabaya: Dewan Kesenian Jawa Timur.

Kusumawijaya, Marco. 2008. "Seni (dan Sastra) dalam Perkembangan Kota: Living Together, Growing Apart? Hidup Bersama, Makin Berpisah", dalam Susastra: Jurnal Susastra dan Budaya, diterbitkan oleh Himpunan Sarjana Kesusastraan Indonesia Volume 4, Nomor 1, halaman 65-91.

Manna, F. Aziz. 2010. Siti Surabaya. Suabaya: Diamond

Manna, F. Aziz. 2010. Wong Kam Pung: Kumpulan Puisi. Surabaya: Festival Seni Surabaya.

Manna, F. Aziz. 2013. Tanggulendut: Himpunan Puisi. Surabaya: Dewan Kesenian Jawa Timur.
Mashuri. 2006. Hubbu. Jakarta: Gramedia Pustaka Utama.

Mashuri. (ed.). 2012. Sulfatara: Pelangi Sastra Malang dalam Puisi. Malang: Pelangi Sastra Malang bekerjasama dengan Resist.

Mashuri. 2013. Munajat Buaya Darat: Kitab Puisi. Yogyakarta: Dress Publising.

Mundzuk, Ifoel. 2004. Syahadat Sukma: Puisi dan Prosa. Lamongan: Pustaka Pujangga.

Para Pengarang Surabaya. 1992. Semangat Tanjung Perak: Kumpulan Puisi Para Penyair Surabaya dan Jawa Timur. Surabaya: Tanpa Penerbit yang jelas.

Para Pengarang Banyuangi. 2002. Menara Tujuh Belas: Antologi Puisi Perjuangan. Banyuangi: Pusat Studi Budaya Banyuangi.

Para Penyair Sumenep. 2007. Setetes Kota Sarung: Antologi Puisi.

Para Penyair Sumenep. 2011. Cahaya Nun: Antologi Puisi. Sumenep: Sanggar Andalas.

Para Pengarang Lamongan. 2013. Waktu yang Hilang dan yang Tertinggal: Kumpulan Puisi. Lamongan: Sudra.

Prasetyo, Arif Bagus (ed.). 2007. Rumah Pasir: Antologi 5 Penyair Jawa Timur. Surabaya: Festival Seni Surabaya 2008.

Ratna, Nyoman Kutha Ratna. 2003. Paradigma Sosiologi Sastra. Yogyakarta: Pustaka Pelajar.

Saryono, Djoko. 2013. Arung Diri: Kitab Puisi. Malang: Aditya Medya Publising.

Scolte, Joh. 2009. Gandroeng dan Banyoewangi. Banyuangi: Pusat Studi Budaya Banyuangi.

Setia, Beni. 2010. Cerita Singkat dan Tafsir Politik. Surabaya: Festival Seni Surabaya 2010.

Singodimayan, Hasnan. 2003. Kerudung Santet Gandrung. Jakarta: Desantara.

Sungkonowati, Yulitin. 2010. “Memetakan Komunitas Sastra Indonesia di Jawa Timur", dalam Atavisme, Vol. 13 No.1, Juni, halaman 101-116. 
Swingewood, Alan and Diana Laurenson. 1972. Sociology of Literature. London: Paladin.

Syah, Sirikit. 1997. Harga Perempuan. Surabaya: Gorong Gorong.

Tjahjadi, Indra. 2011. Syair Pemanggul Mayat: Kumpulan Puisi. Surabaya: Yayasan Seni Surabaya.

Tjahjono, Tengsoe. 2010. Salam Mempelai: Kumpulan Puisi. Lamongan: Pustaka Ilalang.

Tjahjono, Tengsoe. 2013. Yang Bertamu adalah Ilham. Surabaya: Sanggar Kalimas.

Yusuf, Antariksawan \& Hani Z.Noor. 2013. Nawi BKL Inah. Jakarta: Republika.
Widarmanto, Tjahjono. 2013. Masa Depan Sastra: Mosaik Telaah dan Pengajaran Sastra. Sidoarjo-Jawa Timur: SatuKata Books.

Widijanto, Tjahjono. 2011. Janturan: Kumpulan Puisi. Ngawai: Spirit Management.

Widijanto, Tjahjono. 2014. Cakil. Yogyakarta: Pustaka Puitika.

Wiyoto, Ribut, S. Yoga, dan Mashuri. 2009. Pesta Penyair: Antologi Puisi Jawa Timur. Surabaya: Dewan Kesenian Jawa Timur.

Zaki, Rusdi (ed.). 2006. Doa Tangan Tangan: Kumpulan Puisi 34 Penyair Menandai 34 Tahun. Surabaya: Bengkel Muda. 